\title{
Intellectual Kurdistanbul - Approaching Istanbul As A Diasporic Experience
}

\author{
Duygu Örs ${ }^{1}$ \\ European University Viadrina, Frankfurt/Oder, Germany
}

\begin{abstract}
Istanbul is the biggest Kurdish city. This fact, which might look controversial on the first sight, is the outcome of different waves of Kurdish migration to one of the biggest cities in Turkey - a country been direct perpetrator of these migrations. Kurdish migration to Istanbul is very diverse and has created many different experiences of the city. The article will focus on an intellectual Kurdish Istanbul, created and experienced by self-identified Kurdish Istanbulites, who engage with their identity in an intellectual and Kurdophile way.

Keywords: internal diaspora, Kurdish Istanbul, urban ethnography.
\end{abstract}

\section{Introduction}

There is a widely spread saying that might look controversial at first sight but opens up a wide world of thought when looking at it more closely: Istanbul is the biggest Kurdish city. According to the findings of Rüstem Erkan's research in 2010, people with Kurdish background are nowadays mostly centered in Istanbul, Turkey's megacity (Cihan, 2010). Kurdish migration to Istanbul can be traced back to the beginnings of the $19^{\text {th }}$ century and continues today. While the first Kurdish migrants during the Ottoman periods were mostly sent to exile in Istanbul so that possible uprisings in Kurdistan would be prevented (Alakom, 2012, p. 41), the following waves of migration have been directly linked to the Turkish state's hostile incorporation of North Kurdistan. During the "1920s and 1930s, the newly established state of Turkey practiced a de facto politics of colonization vis-à-vis the territory that had become 'the southeast' on its map", imposing "its authority over the peoples living there" and proceeding "to keep the region under firm control thereafter" (Gambetti \& Jongerden, 2015, p. 3). Displacements that came out of this power imbalance are the reason for numerous Kurdish communities living over the world today, and also in particular in Turkey.

As one of the main sites of Kurdish re-settlement in Turkey, Istanbul offers many different urban Kurdish experiences, which cannot be bundled together. The Istanbul that a Kurdish housewife living in the suburbs of the city experiences, differs from the Istanbul lived by a Kurdish builder, working on and living in a construction site in the city. The everyday life of a young Kurd, spending the winter months in Istanbul to work in a night club in Taksim and moving to the coast to work in a hotel in the summer season, cannot be compared to the daily life of a young Kurdish student at one of the best universities in Istanbul. All of these Kurds' social placings within the Turkish society are varied in their ways. They are mostly "differently excluded or included according to factors other than ethnicity and ethno-cultural identification" (Gambetti \& Jongerden, 2015, p. 6), such as the place where they are staying, with whom they are living, how long they are planning to stay and with what aim they came. These factors tell much about the "different engagements and exposures" that all have various impacts on individuals and groups (Gambetti \& Jongerden, 2015, p. 6).

When analyzing these Kurdish lifeworlds, diaspora discourses are not applicable for all. Here, the distinction between migrant and diasporic communities is crucial (O’Connor, 2015, p. 4), since not all Kurdish individuals engage with the idea of a homeland in an active way, which is an important, distinguishing attribute of diasporas. Yet, there is one Kurdish setting in Istanbul which has not gotten any attention as of yet, but provides important insights into Kurdish life in Turkey, and at the same time invites one to rethink the concept of diaspora. The radius for this is mostly located around Istanbul's Taksim Square and its connected İstiklâl Caddesi [Turkish for "Independence Avenue"]. The site is one of the city's main focus points, which gathers thousands of tourists and commuters on a daily basis. Considered historically, Taksim evolved through the twentieth century as a spatial manifestation of the Turkish secular state, with the war of liberation as its momentum of foundation. Today, the square is still a playground for demonstrations of power: while the hegemonial visualizes itself through the tools of architecture and urban planning, the anti-hegemonial claims rights through demonstrations and hidden spatial inscriptions into the public sphere, as I will explain later. In this sense, the "socio-spatial traditions, which shaped and are shaping the square's appearance and meaning, illustrate the contestation over national identity and its discursive practices" (Baykan \& Hatuka, 2010, p. 51).

\footnotetext{
${ }^{1}$ Email: duygu.oers@ posteo.de
} 
One could say that the Taksim area is home to one experience of the city, with those on the move within it being mostly young individuals who identify themselves as Kurds and engage with their Kurdish identity individually on an everyday basis. Since the social fabric of this urban experience is mostly characterized by an intellectual and Kurdophile habitus that transcends the boundaries of any party political or religious affiliation, I shall refer to it as the Kurdish intellectual Istanbul. The present article aims to approach this Istanbul by giving an insight into the interplay of its actors, sites and acts, which can be seen as "disjointed yet parallel practices of noncollective actors" (Bayat, 2009, p. 5) that come together at particular occasions and sites but are not institutionalized under one association.

This Kurdish intellectual Istanbul seems to be constituted of transient encounters on İstiklâl when rushing to a Kurdish play organized by a group of individuals, with kaçak çay ${ }^{2}$ [Turkish for "smuggled tea"] breaks along with deep conversations about Kurdish topics in cafés reached by narrow stairways and suspicious entrances on the backstreets of Taksim, and by the knowledge that guides you through the various passages on İstiklâl which hide Kurdish publishing houses and bookstores. The latter might supply you with Kurdish novels, needed for the next Kurdish reading club sessions, the Şewîr. Gatherings in private homes, where you sit on the floor and eat food that someone's family sent from home are experiences that belong to this Istanbul as well as internet blogs, where you can find out about upcoming Kurdish concerts, author's readings or historic panel discussions.

Within my ethnographical research, I frame this urban Kurdish configuration as a diasporic experience and argue that it plays an important role in the production and formation of Kurdish subjectivities, acts and sites. All together in an interplay, challenging hegemonic racialization and assimilation practices of the Turkish state and society. Whilst the Kurd has always been framed as a "backward citizen" that refused to develop in accordance with the assimilationist formula "Kurd + time = Turk" (Gambetti \& Jongerden, 2015, p. 2), the intellectual Kurdish diasporic Istanbul provokes the Turkish state's framework and positioning of its Kurdish citizens.

\section{Approaching the Kurdish Intellectual Istanbul}

I would like to begin by first taking a step back to zoom out and give a broad definition of the city that will contextualize the Kurdish intellectual Istanbul in a multi-faceted framework. In her definition ${ }^{3}$ of the urban, Kathrin Wildner (2015) notes that cities and metropoles "are not only transnational hubs and cosmopolitan centers, but also areas of conflict and possibility-spaces of societal negotiation" (p. 168). When trying to understand the constitution of a city, the search for "material conditions as well as the social implications, actors, discourses, images and imaginations, which all play an important role in the production of city" is inevitable - all of these make the city to an urban assemblage, "in which power relations and societal structures are being reproduced" and at the same time "continuously negotiated through cultural practices" (Wildner, 2015, p. 169). Thus, the city can be understood as a place of societal localization, a "grounding site of meaning making" when referring to Smith (2001, as cited in Wildner, 2015, p.169).

If we think of Istanbul with all the dimensions that the given definition reveals, and bring these into relation with young Istanbulites engaging with their Kurdishness in an intellectual way, many questions can be asked: in which sense can we talk about Istanbul as a transnational space? What kind of conflicts, possibilities and negotiations does a Turkish city offer for a Kurd? What are the places of everyday lives in the Kurdish intellectual Istanbul, and what kind of knowledge is required to enter and move within these? In what ways does the social and material urban constitution affect Kurdish lives, and how are these manifestations negotiated through cultural practices? Finally, what kind of meaning do young Kurds produce in Istanbul?

This article cannot provide detailed answers to all these questions and should be seen more as a processual paper that adds another spatial perspective to the Kurdish issue (see also Gambetti \& Jongerden 2015). However, I believe that the Kurdish Istanbul needs further consideration in terms of its being, impacts and visions. My approach to the formations of Kurdishness and its dialectical relation to the city of Istanbul is based on the same understanding of Kurdishness as the one of Ramazan Aras. He describes it as "a counter and alternative world", a "state of being in a socio-political and cultural domain constructed by religion, culture, history, ideologies, sociopolitical suffering, and struggle, but not as a homogeneous entity" (2014, p. 39-49). The ways in which this state of being is formed in coherence with intellectual practices will unfold over the following pages.

All of those that have contributed to framing this approach to the intellectual Kurdish Istanbul engage with their Kurdishness differently, therefore their localization within the Kurdish Istanbul varies too. There are ten individuals I have chosen to talk to more closely, five men and five women. Some of them are very active, shaping this Istanbul by organizing events, writing blogs and articles. Others used to play an active role in it, but then chose to move in it more selectively, living the intellectual life more in their own apartments. One person, the youngest, had only just moved to Istanbul to study, and was enthusiastically discovering all the opportunities that the city

\footnotetext{
${ }^{2}$ The expression in Turkish is also used in the linguistic practice in the Northern Kurdistan context with Kurdish accent as "qaçax çay".

${ }^{3}$ Quotes of the definition are translated from German to English by the author of this text.
} 
provides for developing his Kurdish identity. His statements strongly resembled the stories that others told of their first years in Istanbul. He therefore functions arguably as a representative of the experiences that most of these Kurds share in their first years. There are also some that, by choice or of necessity, left this Istanbul for other places, such as Europe, or for other experiences of Istanbul that are not centered around their Kurdish identity.

I was living in this Istanbul myself for a total of two years, and after a while decided to investigate it within an academical setting. An inductive and explorative take was the most suitable setting for my research. ${ }^{4} \mathrm{I}$ conducted this urban ethnographical research between 2017 and 2019, while in 2017 most of the data was collected. From a Kurdish point of view, these years were characterized by desperateness: the Turkish state's decision to end the Kurdish-Turkish peace process abruptly was noticeable in the social and political atmosphere of everyday life. 2010 to 2015 were perceived by many young Kurds as the "glorious years" of Kurdish life in Turkey, with exceptional liberties. The hope to a possible return to these days was defeated for good when the socalled şehir savaşı [Turkish for "city battle"] in the Kurdish cities was answered by the unexpectedly brutal operations [Hendek operasyonlarl, Turkish for "trenches operations"] of the Turkish state.

Since significant aspects of the Kurdish intellectual urban experience are based on such atmospheres, perceptions, affective spheres, visions and implicit knowledges, the use of transdisciplinary and inventive methods was necessary (Streule, 2014; Wildner, 2015, Huffschmid \& Wildner, 2009). Recalling these aspects would exceed the abilities of a solely social-scientific research (Streule, 2014). In this sense, classical anthropological methods such as semi-structured interviews and participant observations were complemented by partially participatory methods, like photo-elicitation, joint associative walks, unorganized conversations and WhatsApp chats, through which pictures and thoughts were shared with me spontaneously.

In this article, a special focus will be given to pictures that were taken with disposable cameras by two of the young Kurds, because, as Ayona Datta also remarks for her research, the methodology of collecting "visual narratives" allows for a profound "exploration of embodied and material aspects of everyday lives in the city" (2012, p. 1725). When handing over the cameras, all five recipients were already familiar with my research, and so I only told them that the topic is still the Kurdish Istanbul and that this is just a way to find everyday aspects of their lives as Kurds. The pictures that I got back have many scenes in common, but also differ in their perceptions and selections of scenes that depict their lives in Istanbul. In the following lines I will show how these scenes can be contextualized within a diasporic experience.

\section{Understanding Istanbul As A Diasporic Experience}

The Kurds are the largest ethnic population without their own nation state. Their past and present was and is still being shaped by modalities of violence, injustice, practices of resistance and routes of dispersion at large. Tracing back people who have Kurdish origins would lead to a worldwide map with many different stories of diasporic experiences. Academic research with a focus on diasporic issues exists in plentitude, however they refer mostly to Kurds finding refuge in European countries like Sweden, United Kingdom or Germany. But there are also cases, in which Kurds resettle internally, meaning within the confines of the official state they are living in. Thus, in terms of citizenship, their legal status does not change (O'Connor, 2015, p. 9). They are mostly referred to as internal diasporas 5 . In the case of the Kurds in Turkey, Cihan Ahmetbeyzade is talking about "new Kurdish localities", which are established "outside of the Kurds' homeland but within Turkey" (2007, p. 161). The Kurdish internal diaspora is thus a setting in which the "host" and the "guest" are in a direct conflictual perpetrator-victimaffiliation, meaning that the Turkish state is actually the cause for Kurds seeking refuge, while, at the same time, is the one that is giving refuge in one of its localities.

There is much academic work which focuses on Kurdish topics in the biggest city of the Turkish state, but only a few of these are framed within diasporic discourses (Ahmetbeyzade, 2007; Houston 2001; O'Connor, 2015). I decided to join these approaches and contextualize the Kurdish intellectual Istanbul as a diasporic experience for the following reasons: all of the young Istanbulites that I worked with perceived the political situation in which they find themselves as a colonial condition. They consider the Turkish State as the dagirker [Kurdish for "colonizer"] and name the place that they and their families are coming from Kurdistan 6 . With this, they are not questioning the existence of Kurdistan, despite a non-existent official state status. In their interviews,

\footnotetext{
${ }^{4}$ As an active part of the circle, I was never the classical but rather an involved researcher with personal and political involvement. From the beginning, I decided to be open about my research and tried to include my friends and other actors in the field into the knowledge production processes as much as possible. Within these processes, I sometimes was the Almancl Kürt [Turkish for "the Kurd from Germany"] that mostly understands but does not speak Kurdish, the wife of a young Kurdish author or the Alman akademisyen [Turkish for "the German academic"] and much more. Integrating all my different roles into a hybrid position made me find a productive balance between distance and closeness and helped to adjust the power relations between me and the field. The "end product" is, however, a compilation and contextualization that I myself in my role as a researcher made (see also Hamm 2013).

${ }^{5}$ The emphasis is also being made here as it is dependent on the perspective one takes to talk of the Kurds being dispersed either across state borders, when proceeding from unofficial state borders of a Kurdistan, or within official state borders, when thinking of Kurdish regions within Turkey. Since I am trying to depict perceptions of the Kurdish individuals that have a strong sense of Kurdistan, talking about an internal diaspora might not represent all the opinions of the Kurdish intellectual diaspora.

${ }^{6}$ Mainly from Northern Kurdistan, the part within the Turkish nation-state borders.
} 
most of the young Kurds express the feeling of being abroad (in Turkish "gurbette olmak") and the desire to return to Kurdistan as their geographical origin. Though the expression of gurbette olmak is also used in other contexts, where, for example, people in Turkey move from a village to a city like Istanbul, in the case of the young Kurds, envisioning a return is not based on the villages or cities that they are actually from, but rather oriented to the bigger cities that would belong to a unified Kurdistan. Cities like Diyarbakir, Van, Mardin and even Hewlêr are preferred places for a possible return. Using the concept of diaspora in this respect allows to place "the discourses of 'home' and 'dispersion' in creative tension, inscribing a homing desire while simultaneously critiquing discourses of fixed origins" (Brah, 2005, p. 193). This means that diaspora and its more general concept of transnationalism, allows for the re-organization of understandings of nation and fixed identities, and the investigation of border-crossing processes contextually (see also Krätke, Wildner, \& Lanz, 2012; Quayson \& Daswani, 2013).

For this article, I follow Francis P. O’Connor's example and use Rogers Brubaker's three core elements of diasporas to structure my approach to the Kurdish intellectual Istanbul. Brubaker defines a dispersion in space, the maintenance of boundaries and an orientation to a homeland as three criteria "widely understood to be constitutive of diasporas" (2005, p. 5). I will elaborate upon these three by briefly introducing the idea behind them, then bring them together with a selection of the collected material on the Kurdish intellectual Istanbul.

\section{Dispersed In The Other's Space}

The word "diaspora" has its origin in the Greek language (dia, 'through' and speirein, 'to scatter') and can be translated as "dispersion" (Brah, 2005, p. 178). Dispersion builds thus the basis, the first and most accepted criterion, of the understanding of diasporas and "can be interpreted strictly as forced or otherwise traumatic dispersion; more broadly as any kind of dispersion in space" (Brubaker, 2005, p. 5). To speak of dispersion in "space" generally allows for the inclusion of dispersions across and within state borders, which then speaks for many more diasporic experiences than other, narrower diaspora definitions that only refer to official nation states.

There are different waves of Kurdish migration to Istanbul that can be identified as "dispersions in space". Back in the early $19^{\text {th }}$ century, the first "concern about Kurdish migrants' present in western Turkey" was documented in Ottoman sources: as the capital of the Ottoman Empire, Istanbul "historically attracted members of the Kurdish tribal elite which doubled as its nascent intelligentsia and was the site of early Kurdish nationalist agitation" (O'Connor, 2015, p. 9). A group of politically active Kurdish intellectuals with a strong consciousness of their Kurdishness, called Jön Kürtler [Turkish for "young Kurds"], organized 1898 the publication of the first Kurdish magazine, called Kurdistan (Ünlü, 2014, p. 417). According to Rohat Alakom, Istanbul, in this sense, was the first center of Kurdish modern ethno-nationalism (2012, p. 93), determining Kurdish nationalism.

With the foundation of the Turkish Republic, new waves of militarily-dispersed forced migrants were added to the Kurdish elite located in Istanbul. O'Connor states that this first wave of traumatic dispersion and deportation built a "historic memory", which "is also the narrative foundation of the contemporary Kurdish diaspora" (2015, p. 9). The second wave, from the 1950s to the 1980s, was started by Turkey's industrialization and urbanization, which caused massive population restructuring, mostly self-initiated. The third wave started in 1984 and lasted until 19997; during this time, Kurdish people were forced from their land because of the state's conflict with the Partiya Karkerên Kurdistanê [Kurdish for 'Kurdistan Worker's Party], PKK (O'Connor, 2015, p. 10). There is a fourth wave, which O'Connor does not consider, but according to Karol Kaczorowski needs to be studied more widely: the new Kurdish migration, bringing young Kurds to Istanbul because of economic and educational reasons (2015, p. 49). Kaczorowski labels the latest form of migration a voluntary one, but I would prefer to frame it as being self-initiated. Since employment-worthy academic degrees can usually only be gained in Turkey's best universities, located not in the Kurdish but Turkish cities of the west, many students who obtain high scores in high school gain places in top study programs. Likewise, the job markets are more promising in the bigger Turkish cities. Here, many young Kurds feel obliged to leave the Kurdish region to provide themselves and their families with better incomes.

The group of young Kurdish Istanbulites in the focus of the research here mostly belong to the fourth wave but are all very conscious of the past waves, in particular the third. This is partially because of family experiences, but mainly because of a thorough "historic memory" (O'Connor, 2015, p. 9) appropriated through related readings, documentations and panel visits. Important Kurdish intellectual and political figures like Celadet Alî Bedirxan, Kamûran Bedirxan, Șerîf Pasha or Îhsan Nurî Pasha, who have all made important contributions to the establishment of the Kurdish language, political ideologies and resistances (Alakom, 2012) are known and honored with their biographies, works and ideas. This goes as far as to attach places to these figures: the famous Galata bridge, for example, is sometimes called Celadet's bridge, as it was known to be one of Celadet Alî Bedirxan's favorite sites. Interestingly, opportunities for engaging with intellectual figures and their works are more available in Istanbul than in any other city of Turkey or northern Kurdistan; many interviewees greatly

\footnotetext{
${ }^{7}$ This conflict is currently active again and forcing people constantly to flee from their homes.
} 
appreciate the possibilities Istanbul has to offer. But how is the space in which these possibilities are embedded perceived?

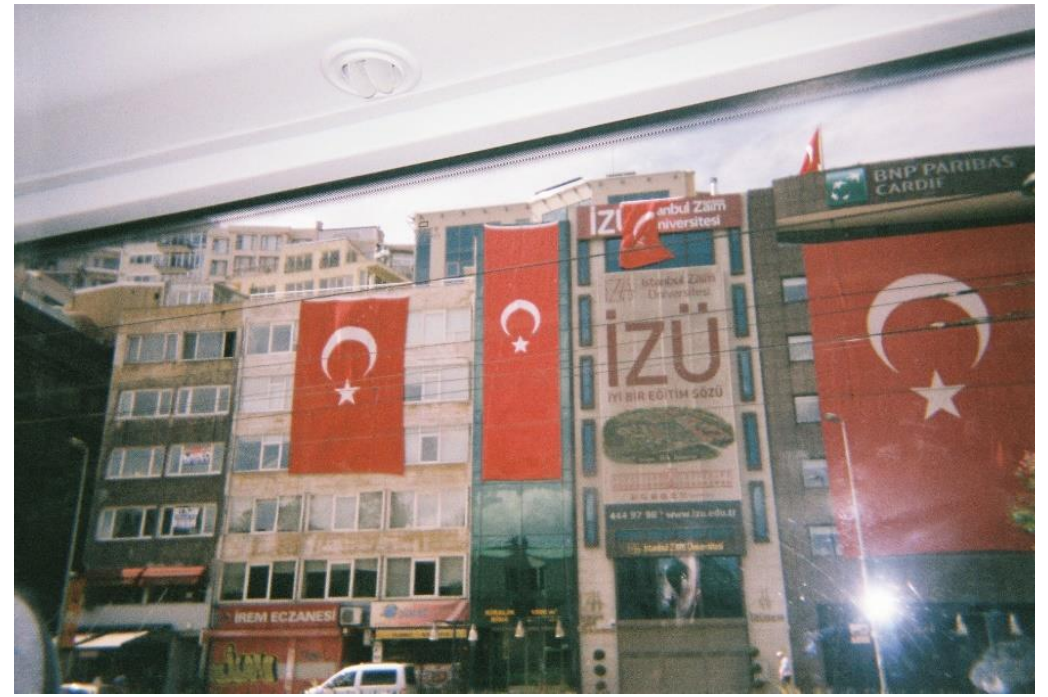

Figure 1. One of Leyla's numerous Turkish-flagged Istanbul scenes, Istanbul. 2017.

A glimpse is given by a picture (Figure 1) by one of the young Kurdish Istanbulites, whom I will refer to here as Leyla. Leyla is actually a student in a small city two hours away from Istanbul. She uses her every studyfree minute to commute to Istanbul, where she is staying at her friend's apartment. What was remarkable about the pictures she took was the amount of urban scenes with Turkish flags. When we talked about these pictures, she described moments in which she suddenly became aware of the flags that surrounded her in so much of her everyday life in the public spaces of Istanbul. She stated that for her, it seems that despite all the Kurdish events and places that Istanbul has, it is "in the end a Turkish city", thus a city of the other.

Leyla described a situation in a café, where she used to meet friends and have conversations in Kurdish. When she noticed the Turkish flag hanging in there, she felt that she could not go there again, although she liked the place a lot. The flag would be a "reminder", a symbol that commemorates the denial of her existence as a Kurd, as she told me. Not only Leyla, but many other young Kurds in Istanbul avoid buying their goods from places with Turkish flags. The flags are mostly perceived as symbolic reminders of a narrative to which many of the Kurds do not feel a positive belonging. This narrative is one of a nationalistic homogeneity that is in many ways reproduced by "spatial maneuvers" (Gambetti \& Jongerden, 2015, p. 7). In the social and physical spaces of the city, the Turkish state applies multiple nationalistic articulations in symbolic and concrete forms. The urban landscape is shaped by masses of flags that give the impression that a place has just been reconquered from the hands of an enemy, lighting systems that blink interchangeably in red and white, the colors of the Turkish flag, as well as slogans inscribed on the walls of huge buildings such as: "Tek Millet, Tek Bayrak, Tek Vatan, Tek Devlet" [Turkish for "One nation, one flag, one homeland, one state"] - a slogan that is used strongly, almost uninterruptedly as a sign of loyalty to a nationalist stance against Kurdish "separatism", throughout the entire nation-state's history up to now, and by almost every Turkish political figure. All these are manifestations of the hegemony that polices the individuals of an "imagined community" (Anderson, 1991) and at the same time functions as a Foucauldian panopticon (Foucault, 1977). They give the feeling of being surveilled and not being allowed to imagine any setting other than that of the Turkish national state. In this hostile condition, the creation of acts and sites that allow for engagement with one's Kurdishness present ways of creative negotiations. In the past and also today, the creation of these "master narratives of homogeneous totality, such as Turkishness, Turkish history, and Turkish language, simultaneously gave birth to counter-hegemonic Kurdish struggles, signifiers, and narratives" (Ahmetbeyzade, 2007, p. 162). These counter-movements are not limited to organized actors like political parties, NGOs and associations, as is often presumed. In fact, envisioning counter-hegemonic action is very much dependent on the definition, and therefore individual intellectual acts like reading books in a language that is permanently contested, and for which you had to organize the reading skills by yourself, can also be seen as part of a larger counter-hegemonic project. In this project, the maintenance of borders plays a crucial role.

\section{Maintaining Boundaries}

The boundary maintenance criterion implies the "preservation of a distinctive identity vis-à-vis a host society" (Brubaker, 2005, p. 6). The most interesting aspect of the Kurdish diaspora in Istanbul is that the host of this diasporic setting is, at the same time, the perpetrator of the diasporic situation. Unequal power relations (which 
shape diasporas in general) are, in the case of this internal diaspora, more distinctive. The formation of an identity by a diasporic subject - in the Kurdish intellectual Istanbul also understood as a colonial subject - takes place in a more hostile environment. The boundaries being set within these conditions have, especially for "collectivities that do not have 'their own' territorial polity", a greater importance than for those with official territories (Brubaker, 2005, p. 6).
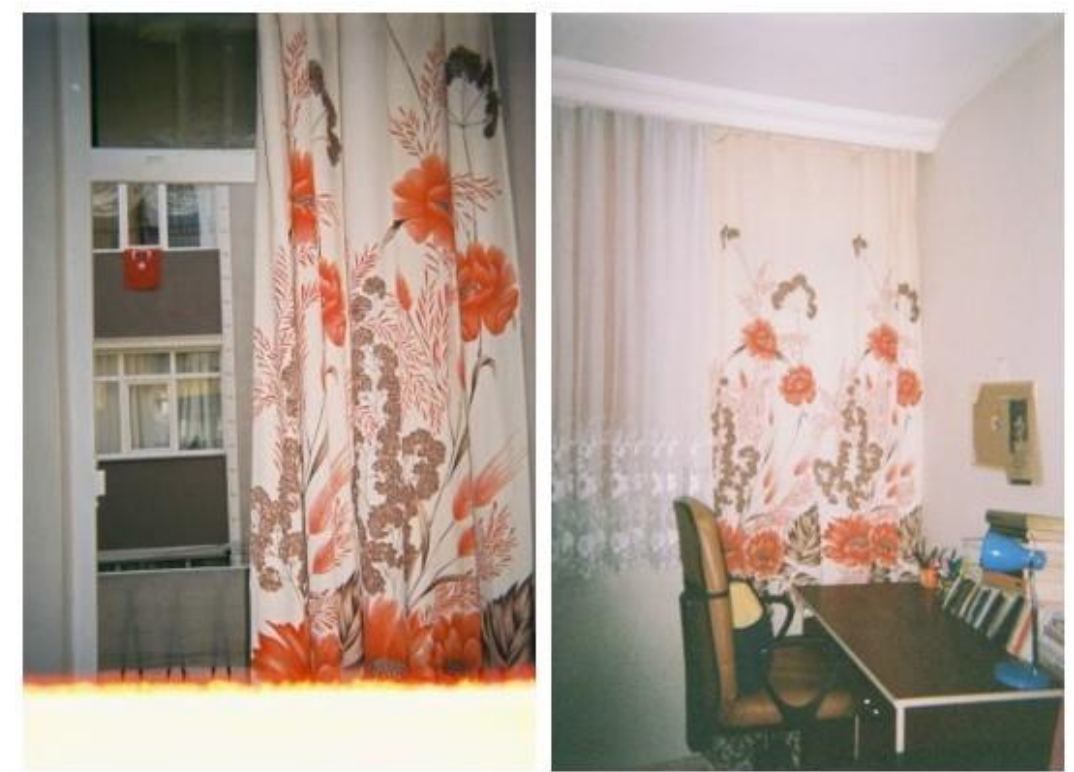

Figure 2. Home and Turkish flag, photographed by Leyla, Istanbul. 2017.

The two pictures in Figure 2 tell a highly symbolic story. When Leyla and I entered this room, Leyla talked proudly about her new curtains, perdeya gulguli [Kurdish for "rosy curtains"], which reminded her so much of her village, where they used to have the same ones. She drew the curtains, saying that this curtain is also a nice way to cover the Turkish flag hanging from the window of her neighbors. In this sense, the act symbolizes a dissociation from outside. When we realize that the flag is a symbolic representation of the hegemonic majority society, then the act of closing the curtains by a Kurdish coded curtain can also be seen as an act of disidentification. It is a refusal of "participation in the network of similarities" that tie together members of a family to which one has been ascribed (Medina, 2013, p. 663). In this case, she as a Kurd denies being part of the "family" that is built on the idea of homogenized citizens identifying or having been made to identify themselves as Turks. This dis-identification or counter-identification confounds existing orders and relations within and across families, inviting a re-articulation of networks and identity categories (Medina, 2013, p. 665).

In the case of the Kurds that move within the Kurdish intellectual Istanbul, dis-identification with the Turkish society is re-articulated by maintaining their boundaries through creating severed safe places. These places provide productive ground through which to evolve as a counter to the Turkish; a Kurdish identity by an intellectual involvement through certain acts and in certain sites. For Leyla, and also for many other Kurds, a crucial place in this context is the home, meaning an apartment, private room or a corner of a room. Leyla's space is multifunctional. It is at the same time a living, bed and study room, and is used for inviting friends from the Kurdish community over for tea, blogging in Kurdish or listening to Kurdish music. There are many pictures of the room, also taken by the person with whom Leyla is staying, that show books on the shelves and that can be understood as manifestations of an intellectual engagement with Kurdish identity, since many of these deal with political theories relevant to the Kurdish question or culturally important novels in Kurdish.

Furthermore, when thinking of the city as a "battlefield, where ideas, ideals and imaginations of different groups are mobilized" (Isin, 2005, p. 375), this picture can be also analyzed as a battle among representative symbols. The one with hegemonic power, a citizen that feels a belonging to the Turkish state narrative, has the right and authority to show their attachment through clear symbols in public, such as the flag. The one without hegemonic power, the pseudo-citizen (Yeğen, 2009), can only have hidden symbols - here, the flowery curtains which are only readable as symbols of Kurdishness for those that have the tacit knowledge to do so. It is an act of displaying belongingness and can be seen as a way to contest their racialized and marginalized Kurdishness by reconfiguring it through intellectual practices. Creating an intellectual Kurdish space offers thus the possibility to demonstrate and perform an alternative, cultural citizenship (Thangaraj, 2015).

Proceeding from thinking Istanbul as a Turkish space, it is interesting to look at the numerous sites outside of the home that constitute the Kurdish intellectual space of Istanbul. Many of these sites are not clearly visible. I remember being lost many times when going to meet friends at the beginning of my stay in the city, since the cafés are mostly located on the upper floors of buildings in the labyrinthian backstreets of Taksim. One has to look for 
certain names, styles and areas, especially in Taksim, that can only be attributed to Kurdish when being able to decode and extract the meanings that make sense in a particular social context (Hall, 1973): the Kurdish intellectual one. Kurdish sites such as cafés, books stores, associations and theaters are the actual locational embodiment of a "subaltern counterpublic" (Fraser, 1990), from which this Kurdish intellectual Istanbul can be analyzed. What puts these sites into the realm of the Kurdish and something opposed to the Turkish is, among other things, the tea being served, references to Kurdish poems in their names, the use of titles with "non-Turkish" letters such as $q$, $w$, $x$, and the atmosphere they provide of being able to talk in Kurdish or about any topic related to Kurds without feeling the need to whisper during some parts of the discussion. Meeting friends in these cafés, joining Kurdish reading clubs, watching Kurdish plays and buying Kurdish books can be analyzed in this framework as oppositional intellectual practices of the everyday life that are performed in the city of the other.

Michel de Certeau's concept about tactics and strategies $(1980,1988)$ provides an interesting base for looking at these practices. In their everyday lives, young Kurds, as parts of the Kurdish intellectual Istanbul, use tactics that are calculated and fleeting moves in the public spaces of Istanbul. These include acts like not being open about your Kurdish blog to your colleagues at work, talking Turkish without any accent at selected moments, or feigning sick to avoid participating in the commemorations of soldiers. These acts are "maneuvers" that are being taken in the "territory of the enemy" (de Certeau, 1988, p. 23). The aim of these acts is to bypass hegemonic power structures that are inscribed in the everyday social dimensions of Kurdish life in Turkey, such as racist comments or ascriptions of being supportive of the so called "separatists" and "terrorists". There are also spacemaking acts, which de Certeau calls "strategies", that enable someone to "circumscribe one's own in a world bewitched by the invisible powers of the Other" (1980, p. 5, emphasis added). Permanent spaces like cafés or bookshops, along with momentary ones such as stretches of the İstiklâl, where Kurdish musicians play their music, are all important strategic sites, and can be understood as interventions in the public realm. However, it is important to note here that these are all spatial places that do not function by themselves, needing to be enacted through individuals that perform certain acts there, which only then label the place as Kurdish or as part of the Kurdish intellectual Istanbul. A café, for example, is only staged as a Kurdish intellectual site when Kurdish actors do things like holding conversations in Kurdish, reading Kurdish books, writing, or organizing an event that engages with Kurdishness and Kurdistan in an intellectual way. It is this social and material fabric in interaction that produces and maintains the Kurdish intellectual Istanbul, or as one also hears being said, Kurdistanbul.

When trying to locate this intellectual Kurdistanbul by its strategically-conquered places on actual maps, one would have various little dots spread over the whole city. Many of these dots would be stable, others would be wandering and fleeting, since they are only enacted in transient moments when, for example, conversations in Kurdish are held, when books only found in a few select shops are carried through the city, when groups of individuals occupy a space in a café to talk about these books, and when hidden spaces are taken over and transformed to safe spaces. Further to these dots, one could also draw lines that depict the mental attachments that move in the local spaces of Istanbul's intellectual Kurdish diaspora. They would reach the geographical Kurdistan, but also to other diasporic spaces such as Stockholm or Paris, which are seen as important places of diaspora, with glorious intellectual productions. Visualizing these dots and lines in the mind, I believe that one can understand the Kurdish intellectual Istanbul as a transnational space - one that constantly recalls and produces real and imaginary ideas of Kurdistan that are assembled by narrations of the past, experiences of the present, and visions for the future. Hence, the conception of Kurdistan here is within intellectual borders, that transcends the power of territory and nation-states.

\section{Orientating Towards A Homeland}

Always, when thinking about something dispersed, inevitably, the idea of a focal point from which the dispersion sets out occurs. This focal point is mostly linked to a certain notion of a geographical origin, a homeland, and a return to it. When being dispersed into Istanbul, the city of the other, the awareness of Kurdistan as the place of origin grows into a subject of great importance. I would like to link this typical diasporic development to the encounters in the city that reveal the differences between individuals and spark a "passionate research" (Said, 1985, as cited in Hall, 1994, p. 223) for an original identity. According to Engin Isin, the city functions in this sense as a difference machine, which "generates differences and assembles identities" (2005, p. 375). Becoming aware of these differences is a crucial moment for many of the young Kurds. O'Connor notices that feelings of alterity, experienced through "communal exclusion or a feeling of extraneousness from Turkish majority, largely define Kurdish existence in the west" of Turkey (2015, p. 12). In fact, my interviews and conversations showed that many, especially the ones that do not come from families with a political background, are made aware of being Kurdish as something "negative" and different to Turkish, in the settings of Turkish cities. Many of the situations are triggered by the use of their mother tongue, for which they often experience racialization in public spaces. 


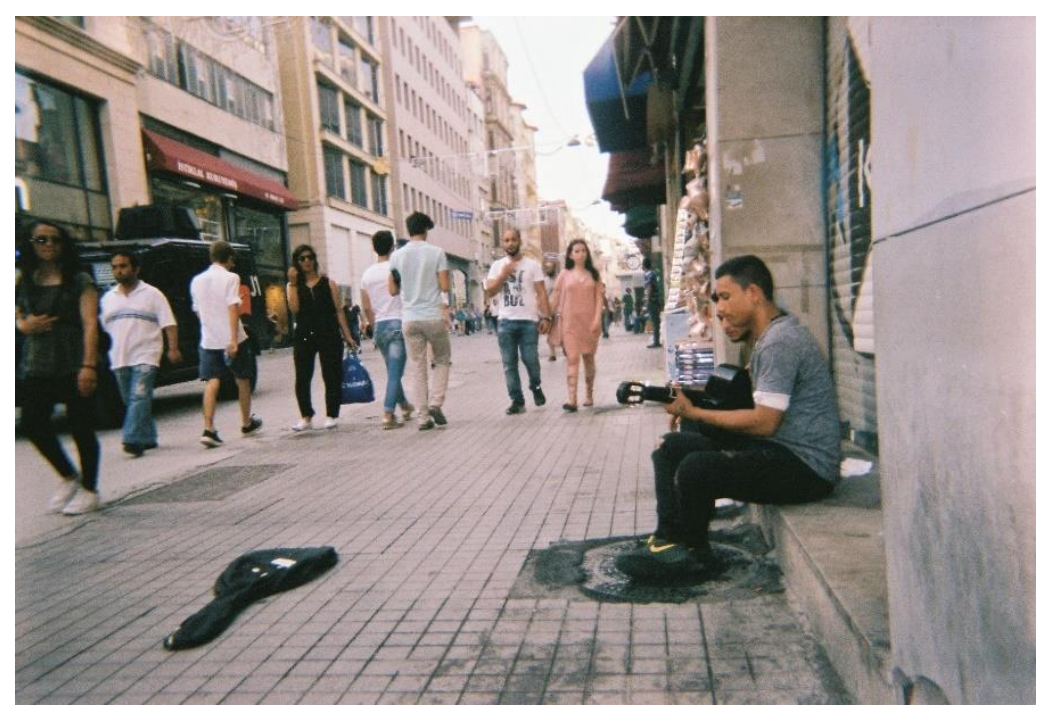

Figure 3. Kurdish musicians on İstiklâl, photographed by Nuri, Istanbul. 2017.

I would like to add Figure 3 here, which gives an example of the importance of the language and its links to homeland. This photograph was taken by Nuri, who is a very active figure in the Kurdish intellectual Istanbul. He writes a blog, publishes a magazine, and takes pictures of Kurds that engage with Kurdishness through music, poetry, literature etc. He hesitated to take the camera and told me that he actually does not have a good association with disposable cameras. When he was younger and living still in his village in Kurdistan, a group photo with an acquaintance was taken right before that person made a çıkış [Turkish for "exit"], an expression that is been used in the sense of exiting the system or climbing on to the mountains, meaning to join the PKK. Unfortunately, all the pictures except that one with this person had been developed, so he never saw him again. Still, he decided to take part in the photo project and was very happy that the picture above caught an important moment, representative of Kurdish life in Istanbul. Figure 3 shows a group of Kurdish musicians on İstiklâl that were singing a song in Kurdish, and which included the word "Kurdistan". At that moment, as a police vehicle was passing, the singer changed "Kurdistan" to "Gulistan" [Persian for "Rose Garden"] - used in some circumstances in the Kurdish context metaphorically for "Kurdistan" - to avoid any complication, since the word is forbidden by the Turkish state's law.

Interestingly, scenes with Kurdish musicians on İstiklâl are one of the many common ones photographed within this project. I believe that this is not because of the music itself, but more because of the Kurdish language creating transient alliances between the people that stop to listen. Here, solidarities are created on the basis of Kurdish as the language that has experienced immense dimensions of suffering throughout the whole history of the Turkish republic, and somehow managed to resist violent assimilation attempts. The use of the language thus has a symbolic meaning here. In fact, Kurdish songs on İstiklâl often drown out singings of the İstiklâl Marşı [Turkish for "Independence March"] that commemorates the founder of the Turkish republic, Mustafa Kemal Atatürk, on almost every day by some other Taksim musicians. The Kurdish musicians of Taksim are also the only ones to find a physical establishment, not in the backstreets, but actually on the wide, main street of İstiklâl, even if it is only momentary.

The resisting power that language has can be underlined by the words of Ahmetbeyzade, who stated that the Kurdish language, with its different dialects, has to be understood as "sites for marking Kurdish culture and symbolically representing Kurdistan” (2007, p. 163). This representation of Kurdistan through language is, especially in the Kurdish intellectual Istanbul, of great importance. In fact, being able to speak, understand and read in Kurdish is not only the key knowledge to fully participate in the social fabric of this Istanbul, it is much more the foundation on which Kurdistanbul is built. Moving within this Istanbul also means learning, or trying to learn, different dialects of Kurdish at Kurdish language institutes, reading early Kurdish publications, writing in Kurdish and meeting friends with whom you can have solely Kurdish conversations. Using the Kurdish language can thus be seen as the very performance of Kurdish identity that is formed as counter to the hegemonic state apparatus, and is believed to be fulfilled when the connections to the origin, that get lost in colonial and diasporic conditions, "are once more set in place" (Hall, 1994, p. 225).

The idea of returning to the geographical homeland as the localization of the origin is very much present among the young Kurds of the Kurdish intellectual Istanbul. Their experiences with returns, either as short family visits or longer work projects, are mostly similar. There is a shared dilemma, which many of the people I talked to described: in Istanbul, you have many times thought of leaving to go back and "serve your homeland and your people with your gained knowledge", but when you are in Kurdistan, even just for a holiday, you mostly feel disconnected and an have intense need to get back to Istanbul. In one of my interviews, Ibrahim, a young Kurdish author, expressed this problem in the following words: 
I mean, I actually created my Kurdistan in Istanbul. (...) It is as if you are physically here but mentally always there, many of us live this dilemma. (...) The notionally-created Kurdistan in Istanbul and the Kurdistan in Kurdistan are not the same, unfortunately. (...) It is as if in Istanbul, we are more Kurdistanian than anyone else (...) Intellectually, from the lifestyle ... But when we go to Kurdistan and live there with the local people, then unfortunately we are much less Kurdistanian.

The problem with returns is that they present the cleft between the Kurdishness that is created and lived in Istanbul and the Kurdishness that constitutes the reality of many of the young Kurds' families in their Kurdish villages. ${ }^{8}$ The confrontation that happens here is based on the social production of two supposedly alike subjectivities, meaning being Kurds. From the ideological perspective of the young Kurd, which is formed mainly by an intellectual engagement with a certain Kurdishness in Istanbul, there should be no aggravating differences between a Kurd in the village and a Kurd in the city. But the lived experiences are different and underline the critique on essential identities. Ibrahim described a highly symbolic manifestation of this distortion. The Kurdish that he adapted in the intellectual Kurdistanbul through readings and academic language classes could not be understood by his mother, who was living in a village in Northern Kurdistan. He underlined that he was not aware of how his language was being transformed in Istanbul until his mother asked him why he spoke in "such a weird way".

When we now recapitulate the idea of the Kurdish language being a site of Kurdistan, then we can say that the practices of the intellectual Istanbul generate two different Kurdistans that exist simultaneously and have both real and imagined aspects. Homeland can, in this sense, be a lived space between being both here and not there (Ahmetbezyade, 2007, p. 166), or "a mythic place of desire in the diasporic imagination (...) a place of no return, even if it is possible to visit the geographical territory that is seen as the place of 'origin'" (Brah, 2005, p. 189).

\section{Conclusion}

The Kurdish intellectual Istanbul gives a sense of how living within the confines of the same official state borders affects the everyday life of individual Kurds that refuse to subordinate to the homogenizing meta narratives of the hegemonic state and its society. Istanbul, the great city of the Turkish state, is here lived as a diasporic space, in which young Kurds find many possibilities as well as conflicts, which always seem to be negotiated in a dialectical relation anew and bring forth creative ways of engaging with various facets of their suppressed Kurdish identities.

The spaces that these young Kurds occupy in Istanbul are actually in-between spaces that are being opened through ways of coding them as Kurdish and enacting them in interplay by the ones that use them. In these permanent and temporary sites of Kurdistanbul, young Kurds take their right to their own mother language and produce safe counter-publics as silent resistance to the hegemonic and oppressive system of the Turkish state and society. Thus, the creation of acts and sites that allow for engagement with one's Kurdishness intellectually present ways for creative negotiation with the hostile condition. This engagement, however, also brings dilemmas within itself. Being excluded when refusing the assimilation machineries of the state and sticking to or nourishing your Kurdish identity, while at the same time not being allowed to imagine any other setting than the one of the Turkish national state, becomes even more complicated. The reason for this is that out of the diasporic condition, two homelands emerge for the young Kurds, which are enacted in different social contexts and lead to conflicts and misunderstandings when they come together.

This approach to the Kurdish intellectual life as a diasporic experience shows that Istanbul is, for the young Kurds, a "grounding site for meaning making" (Smith 2001) of their dispersion into the city, of a decision to orientate towards an idea of a homeland and to a playful drawing of boundaries vis-à-vis Turkish society. This meaning is embodied in the mental and material manifestations of a Kurdistanbul, that is specifically particular for this diasporian setting. But it also implies many aspects that can be translated to other contexts in which diasporic or colonized subjectivities find themselves in their everyday lives, and invites to find creative - inter- or transdisciplinary - ways to review concepts of identity, transnationalism, power and resistance.

\section{References}

Ahmetbeyzade, C. (2007). Negotiating Silences in the So-Called Low-Intensity War: The Making of the Kurdish Diaspora in İstanbul. Signs, 33(1), 159-182. doi:10.1086/518315

\footnotetext{
${ }^{8}$ A vivid insight to this confronting experience of Kurdishness or Kurdistan is given by Aktaş (2017).
} 
Aktaş, B. A. (2017, August 23): Jön Kürdüm, jön Kürtsün, jön Kürt. basnews. Retrieved from http://www.basnews.com/index.php/tr/opinion/konuk-yazar/372915

Alakom, R. (2012). Eski İstanbul Kürtleri. Istanbul, Turkey: Avesta.

Anderson, B. (1991). Imagined communities: Reflections on the origin and spread of nationalism. London, UK: Verso.

Aras, R. (2014): The formation of Kurdishness in Turkey. Political violence, fear and pain. Abingdon, OX; New York, NY: Routledge.

Bayat, A. (2009). Life as politics: How ordinary people change the Middle East. Cairo, Egypt: American University in Cairo Press.

Baykan, A., \& Hatuka, T. (2010). Politics and culture in the making of public space: Taksim Square, 1 May 1977, Istanbul. Planning Perspectives, 25(1), 49-68. doi:10.1080/02665430903421734

Brah, A. (2005). Cartographies of diaspora. Contesting identities. London, UK; New York, NY: Taylor \& Francis e-Library.

Brubaker, R. (2005). The 'diaspora' diaspora. Ethnic and Racial Studies, 28(1), 1-19. doi:10.1080/0141987042000289997

Cihan. (2010, March 25). En büyük Kürt şehri, İstanbul. Timeturk, Retrieved from https://www.timeturk.com/tr/2010/03/25/en-buyuk-kurt-sehri-istanbul.html

Datta, A. (2012). 'Where Is the global city?' Visual narratives of London among East European migrants. Urban Studies, 49(8), 1725-1740. Retrieved from http://www.jstor.org/stable/26150956

de Certeau, M. (1980). On the oppositional practices of everyday life. Social Text, 1(3), 3-43.

de Certeau, M. (1988). Kunst des Handelns. Berlin, Germany: Merve Verlag.

Foucault, M. (1977). Discipline and punish: The birth of the prision. New York, NY: Vintage Books.

Fraser, N. (1990). Rethinking the Public Sphere: A Contribution to the Critique of Actually Existing Democracy. Social Text, (25/26), 56-80. doi:10.2307/466240

Gambetti, Z., \& Jongerden, J. (Eds.). (2015). The Kurdish issue in Turkey. A spatial perspective (1 ${ }^{\text {st }}$ ed., pp. 1-24). Abingdon, UK; New York, NY: Routledge.

Hall, S. (1973). Encoding and Decoding in the Television Discourse. Paper for the Council of Europe Colloquy on "Training In The Critical Reading of Television Language", Birmingham, UK: University of Birmingham. Retrieved from https://www.birmingham.ac.uk/Documents/collegeartslaw/history/cccs/stencilled-occasional-papers/1 to8and11to24and38to48/SOP07.pdf

Hall, S. (1994): Cultural Identity and Diaspora. In Williams, P. \& Chrisman, L. (Eds.), Colonial discourse and post-colonial theory: a reader. ( $1^{\text {st }}$ ed., pp. 227-237). London, UK: Routledge.

Hamm, M. (2013). Engagierte Wissenschaft zwischen partizipativer Forschung und reflexiver Ethnographie: Methodische Überlegungen zur Forschung in sozialen Bewegungen. In B. Binder, F. von Bose, K. Ebell, S. Hess \& A. Keinz (Eds.), Eingreifen, Kritisieren, Verändern!? Interventionen ethnographisch und gendertheoretisch. ( $1^{\text {st }}$ ed., pp. 55-72). Münster, Germany: Verlag Westfälisches Dampfboot.

Houston, C. (2001), Profane Intuitions: Kurdish Diaspora in the Turkish City. The Australian Journal of Anthropology, 12, 15-31. doi:10.1111/j.1835-9310.2001.tb00060.x

Huffschmid, A. \& Wildner, K. (2009). Räume sprechen, Diskurse verorten? Überlegungen zu einer transdisziplinären Ethnografie. Forum Qualitativer Stadtforschung, 10(3). Retrieved from http://www.qualitative-research.net/index.php/fqs/article/view/1224/2834

Isin, E. F. (2005). Engaging, being, political. Political Geography, 24, 373-387. Retrieved from https://doi.org/10.1016/j.polgeo.2004.07.002

Kaczorowski, K. (2015). Towards The study of new Kurdish migration in Turkey. Frittilaria Kurdica. Bulletin of Kurdish Studies, 7-8, 38-55. Retrieved from https://core.ac.uk/download/pdf/53135849.pdf

Krätke, S., Wildner K., \& Lanz, S. (Eds.). (2012). Transnationalism and urbanism. (1 ${ }^{\text {st }}$ ed., pp. 1-30). Abingdon, UK; New York, NY: Routledge.

Medina, J. (2003). Identity trouble. Philosophy \& social criticism, 29(6), 655-680. doi:10.1177/0191453703296002

O’Connor, F. P. (2015). Radical political participation and the internal Kurdish diaspora in Turkey. Kurdish Studies Journal, 3(2), 3-25. Retrieved from https://EconPapers.repec.org/RePEc:mig:ksjrnl:v:3:y:2015:i:2:p:151-171

Quayson, A. \& Daswani, G. (2013). A companion to diaspora and transnationalism. Malden, MA: WileyBlackwell.

Smith, M. P. (2001). Transnational Urbanism: Locating Globalization. Oxford, UK: Blackwell.

Streule, M. (2013). Trend zur Transdisziplinarität: Kritische Einordnung einer ambivalenten Praxis qualitativer Stadtforschung. Forum Qualitativer Stadtforschung, 15(1). Retrieved from https://www.ssoar.info/ssoar/handle/document/37702

Thangaraj, S. I. (2015). Desi hoop dreams: Pickup basketball and the making of Asian American masculinity. New York, NY: New York University Press. 
Ünlü, B. (2014). Kürdistan/Türkiye ve Cezayir/Fransa: Sömürge Yöntemleri, Siddet ve Entelektüeller. In: Çeğin, G. \&, Şirin, I. (Eds.). Türkiye'de Siyasal Şiddetin Boyutları (1 ${ }^{\text {st }}$ ed., pp. 403-434). Istanbul, Turkey: İletişim Yayınları 1978.

Wildner, K. (2015). Inventive methods: Künstlerische Ansätze in der ethnographischen Stadtforschung. ethnoScripts: Zeitschrift für aktuelle ethnologische studien, 17(1), 168-185. Retrieved from https://journals.sub.uni-hamburg.de/ethnoscripts/article/view/810

Yeğen, M. (2009). "Prospective-Turks" or "pseudo-citizens:" Kurds in Turkey. Middle East Journal, 63(4), 597615. Retrieved from http://www.jstor.org/stable/20622956 